rheumatic lesions which follow a febrile illness (e.g. rheumatic fever); and for so-called "psychogenic" rheumatism.

5. The fibrositic lesion is the basic unit of rheumatic disease, which presents characteristic appearances in joints only because of the special qualities of the articular structures.

6. Reference is made to the fact that the clinical teachers of last century generally took the view that rheumatism was a disorder of the central nervous system.

\section{REFERENCES}

Charcot, J. M. (1877). Lectures on Diseases of the Nervous System. London. New Sydenham Society.

Copeman, W. S. C. (1943). Annals of the Rheumatic Diseases, 3, 222 (1944). Ibid., 4,11.

Douthwaite, A. H. (1945). Med. Annual, p. 70.

Duckworth, D. (1880). Brain, 3, 1.

Ernstene, A. C., and Kinell, J.'(1940). Arch. intern. Med., 66, 800.

Gardner, E. D. (1942). Anat. Rec., 83, 401.

(1944). J. Comp. Neurol., 80, 11.

Gasser, H. S. (1937). Harvey Lectures (1936-37), 32, 169.

Head, H., Rivers, W. H. R., and Sherren, J. (1905). Brain, 28, 99.

Hinsey, J. C., and Phillips, R. A. (1940). J. Neurophysiol., 3, 175.

Hubble, D. (1943). Brit. med. J., 1, 121, 154.

Kelikian, H. (1943). Surg. Gynec. Obstet., 76, 469

Kellgren, J. H. (1938). Clin. Sci., 3, 175.

Kellgren, J. H. (1938). 35.

Kelly, L. C. (1943). Ohio State med. J., 39, 26.
Kelly, M. (1944a). Med. J. Austral., 1, 286.

(1944b). Annals of the Rheumatic Diseases, 4, 46.

(1945). Ibid., 5, 1.

- (1946). Ibid., 5, 69

King, E. S. J. (1930). Brit. J. Surg., 18, 113.

Knaggs, R. L. (1932). Ibid., 20, 113, 309.

(1933). Ibid., 20, 425.

Latham, P. W. (1886). Lancet, 1, 626, 673, 723, 771, and 817.

Laycock, $T$. (1864). The Principles and Methods of Medical Observation and Research. Edinburgh. 2nd ed., Maclachlan and Stewart.

Lewis, T. (1942). Pain. New York. Macmillan.

and Kellgren, J. H. (1939). Clin. Sci., 4, 47.

Liveing, E. (1873). On Megrim, Sick Headache, and Some Allied

Disorders. London. Churchill.
Livingston, W. K.(1943). Pain Mechanisms. New York. Macmillan. Mackenzie, J. (1920). Symptoms and their Interpretation. London. 4th ed. Shaw.

Maclagan, T. J. (1896). Rheumatism; its Nature, its Pathology, and its successful Treatment. London. Black.

Maximow, A. A., and Bloom, W. (1934). Text-Book of Histology. Philadelphia. 3rd ed. Saunders.

Mitchell, J. K. (1831). Amer. J. med. Sci., 8, 55. (Cited by Latham.)

Mitchell, S. Weir (1872). Injuries of Nerves and their Consequences. Philadelphia. Lippincott.

Ord, W. M. (1880). Brit. med. J., 1, 155.

Ord, W. M. (1880). Brit. med. J., 1, 155. J. (1879). Clinical
Longmans, p. 431.

Pemberton, R., and Sculi, C. W. (1943). Ann. intern. Med., 19, 482.

Plewes, L. W. (1940). Brit. J. Surg., $27,682$.

Poynton, F. J. (1936). J. State Med., 44, 349.

and Schlesinger, B. (1937). Recent Advances in the Study of Rheumatism. London. 2nd ed. Churchill.

Seddon, H. J. (1943). Brain, 66, 237.

Sharpey-Schäfer, E. (1927). Ibid., 50, 538.

Stockman, R. (1904). Edinb. med. J., 15, 107, 223.

(1911). Brit. med. J., 1, 352.

Stone, S. (1943). J. nerv. ment. Dis., 97, 638.

Trotter, W., and Davies, H. M. (1909). J. Physiol., 38, 134.

\title{
EPILOGUE TO THE SERIES ENTITLED "THE NATURE OF FIBROSITIS"
}

\section{MICHAEL KELLY}

No claim is made that a new hypothesis has been propounded, for a neural theory of rheumatism is two hundred years old. The present observations represent merely the collected observations of many others, perhaps co-ordinated a little and brought up to date with modern neurophysiology. Plenty of corroborative evidence is to hand in the literature, did one but take the trouble to collect it.

No claim is made, either, that the "cause" of rheumatism has been discovered; rather is it suggested that the mechanism has been traced through which the various causes bring about their endresults. There is no single cause for this group of diseases; more likely it is the result of a number of causes, which in different cases may be different, though perhaps acting through the same mechanism. To the casual glance a stiff neck does not resemble rheumatoid arthritis; but neither does a furuncle resemble chronic osteomyelitis, and in the days before Lister it would not have been easy to believe that they were due to the same cause. By agreeing to speak of " rheumatism ", we all display our belief in the basic unity of rheumatic disease; but, with no clear view of its essential nature, we are forced to divide it up into a number of separate " entities", which may prove to be as closely linked to each other as the various staphylococcal infections are linked to each other.

The proposed theory, it is feared, has not dramatic appeal enough to shake the old-established beliefs even in their present confused state. It demands a retracing of the steps over some sixty years, and the discarding of much that we have been taught to accept as self-evident. Even supposing it to be true, many may wonder if it is useful, because it opens up no royal road to the prevention or the cure of rheumatic disease. The answer, of course, is that the truth should be sought at all costs, for itself alone. If the theory is proven to be erroneous, no harm will have been done, for it has been well said that truth is more likely to emerge from error than from confusion.

It has been wisely stated, also, that the value of hypothesis lies not so much in the ingenuity of invention as in the labour of verification. The verification of this hypothesis depends upon the painstaking and careful observation of mild and transient cases of somatic pain, and of early cases of rheumatic disease. Rheumatism clinics rarely see such common affections as the transient spreading pains which sometimes follow mild injuries or infections; and these, perhaps, could throw a good deal of light upon the mechanism of the rheumatic process. They usually remain in the hands of the general practitioner; there can be little doubt, therefore, that the observant general practitioner holds the key to the situation. 